Eur. J. Clin. Chem. Clin. Biochem.

Vol. 29, 1991, pp. 115-119

(C) 1991 Walter de Gruyter \& Co.

Bcrlin - New York

\title{
The Isomer Ratios of Urinary Coproporphyrins I - IV are pH-Dependent ${ }^{1}$ )
}

\author{
By K. Jacob, E. Egeler, B. Hennel, P. Luppa and D. Neuneier \\ Institut für Klinische Chemie (Direktor: Prof. Dr. D. Seidel) am Klinikum Großhadern der Universität München
}

(Received August 13/November 1, 1990)

\begin{abstract}
Summary: The percentage of porphyrinogens as related to total porphyrin excretion was determined in the urine of healthy subjects. Acidic urines ( $\mathrm{pH} 5.0$ to 5.9) contained $62.9 \pm 10.7 \%(\overline{\mathrm{x}} \pm \mathrm{s}, \mathrm{N}=11)$ porphyrinogens, whereas in neutral urines ( $\mathrm{pH} 6.0$ to 7.2$)$ a somewhat lower percentage $(51.2 \pm 15.3 \%, \mathrm{~N}=11$ ) was detected. However, there was no significant difference between the mean porphyrinogen contents of acidic and neutral urines.
\end{abstract}

Evidence was found for a previously unreported $\mathrm{pH}$-dependent influence on the isomer ratios of urinary coproporphyrins I and III. Acidic urines $(\mathrm{N}=18)$ from healthy subjects showed significantly higher percentages of isomer I $(27.1 \pm 6.4 \%)$, isomer II $(2.7 \pm 1.1 \%)$, and isomer IV $(5.0 \pm 1.3 \%)$ as compared to respective values from neutral urines $(22.2 \pm 5.1 \%$ isomer $\mathrm{I}, 0.6 \pm 0.6 \%$ isomer II, and $1.5 \pm 1.3 \%$ isomer IV; $N=16$, $\mathrm{p}<0.001)$. Conversely, the percentage of isomer III was markedly lower in acidic urines than in neutral urines $(65.1 \pm 7.9 \%$ vs. $75.9 \pm 5.4 \% ; p<0.001)$. The same relationship was confirmed in an individual subject by analysis of a series of urines $(\mathrm{N}=13)$ with $\mathrm{pH}$ values ranging from 5.4 to 7.3. These results point to the possibility that the atypical coproporphyrin isomers II and IV are predominantly formed by an increased isomerization rate of coproporphyrinogens under acidic intravesical conditions.

\section{Introduction}

Coproporphyrins of the series I and III are the principal isomers to be excreted in human urine, whereas the atypical isomers II and IV are only present in small amounts $(1-3)$. It has been suggested that formation of the latter results from non-enzymatic self-isomerization of the naturally occurring coproporphyrinogens (3). Porphyrinogens are the metabolically active intermediates in the biosynthesis of haem. They are easily oxidized to the corresponding porphyrins in vivo and in vitro. Both porphyrinogens and porphyrins are excreted in urine (4). The proportion of porphyrins and their reduced precursors has been determined by various methods in urine of both porphyric patients $(5-7)$ and healthy controls (7).

1) Presented in part at the conference "Biochemische Analytik 90", Munich, Germany.
In the course of systematic investigations on the formation of the atypical coproporphyrins II and IV by means of isocratic ion-pair high-performance liquid chromatography (HPLC), we previously observed a stringent influence of urinary $\mathrm{pH}$ on the respective isomer ratios (8).

Here we report our subsequent studies on the influence of urinary $\mathrm{pH}$ on porphyrinogen excretion and on the isomer ratios of the individual coproporphyrins I-IV.

\section{Materials and Methods \\ Individuals investigated}

Spontaneous urine samples of apparently healthy persons of the laboratory staff were used in the study. One of us (P. L.) took voluntarily part in the enforced $\mathrm{pH}$ shifting experiment. Acidic urines were obtained by a high intake of ascorbic acid (up to $5 \mathrm{~g}$ per day), while neutral and alkaline urines were produced after ingestion of large doses of sodium-potassiumhydrogen citrate (up to $10 \mathrm{~g}$ per day). 
Determination of the porphyrinogen excretion in urine

A 2.0-ml urine sample was applied to a disposable anionexchange column (AG1-X8, 50-100 mesh, BIO-RAD, Munich, Germany) shortly after excretion. Interfering substances were removed with water. The porphyrins were eluted with $4 \mathrm{ml}$ $3 \mathrm{~mol} / \mathrm{l} \mathrm{HCl}$ and quantitated by recording the second derivative spectra of the Soret band in the wavelength range between 450 and $350 \mathrm{~nm}(9)$.

Another 2.0-ml sample of the same urine specimen was oxidized for $10 \mathrm{~min}$ at room temperature with a solution of $2 \mathrm{mg} \mathrm{I}_{2}$ and $4 \mathrm{mg} \mathrm{KI}$ in $2 \mathrm{mll}$ water. The surplus of iodine was removed with $\mathrm{Na}_{2} \mathrm{~S}_{2} \mathrm{O}_{3}$. Total porphyrins were isolated and quantified as described above. To calculate the relative porphyrinogen excretion, the increase of peak height after oxidation was divided by the peak height of the corresponding total porphyrins.

\section{Preparation of urine samples for isomër analysis}

Urine samples ( $50 \mathrm{ml}, \mathrm{pH} \mathrm{s-7)}$ were oxidized with a solution of $50 \mathrm{mg} \mathrm{I}_{2}$ and $100 \mathrm{mg} \mathrm{KI}$ in $10 \mathrm{ml}$ water immediately after excretion. The mixture was allowed to react $10 \mathrm{~min}$ at room temperature. Excess iodine was eliminated with $\mathrm{Na}_{2} \mathrm{~S}_{2} \mathrm{O}_{3}$, and subsequently $50 \mathrm{ml} 3.7 \mathrm{~mol} / \mathrm{l} \mathrm{H}_{3} \mathrm{PO}_{4}$ were added. The porphyrins were adsorbed on Sep-Pak $C_{18}$ cartridges (Waters, Eschborn, Germany) and eluted with methanol/acetone $(1+1$, by vol.). The solvents were removed under vacuum, and the residue was neutralized with aqueous sodium acetate, then adjusted to $\mathrm{pH}$ 3.5 with acetic acid. After adsorption on $200 \mathrm{mg}$ talc (E. Merck, Darmstadt, Germany) the porphyrins were eluted with $10 \mathrm{ml}$ methanol/ $\mathrm{H}_{2} \mathrm{SO}_{4}(10+1$, by vol.). The eluate was diluted tenfold with water and the porphyrins were adsorbed again on Sep-Pak cartridges as described. The isolated porphyrins were dissolved in $200 \mu \mathrm{l}$ of $50 \mathrm{mmol} / \mathrm{l}$ methanolic tetrabutylammonium phosphate prior to HPLC analysis.

\section{HPLC analysis}

The simultaneous separation of the coproporphyrin isomers I-IV was achieved by isocratic ion-pair HPLC on a $\mathrm{Li}$ Chrospher RP-18 column (2).

The proportions of the individual isomers were calculated from the respective peak area ratios.

\section{Results and Discussion}

\section{Excretion of urinary porphyrinogens}

A pH-dependent excretion of urinary porphyrinogens was investigated by analysing the porphyrinogen fraction of 22 freshly passed urine specimens. Urinary $\mathrm{pH}$ ranged from 5.0 to 7.2. Total porphyrinogens were determined by assaying the specimens with and without iodine oxidation.

The proportion of porphyrins occurring as porphyrinogens was somewhat higher in acidic urines $\mathrm{pH} 5.0$ to 5.9) in comparison with that in nearly neutral urines (pH 6.0 to 7.2) (tab. 1). The mean contents, however, did not differ significantly. We found porphyrinogen percentages between 23 and $76 \%$ (tab. 1). Similar amounts were present in the urine of porphyric patients $(5,6)$ and in healthy controls $(7)$.
Tab. 1. Porphyrinogen content of 22 freshly passed urine specimens. Data are expressed as percentage of total porphyrin excretion.

\begin{tabular}{llll}
\hline Urine $\mathrm{pH}$ & $\mathrm{N}$ & $\overline{\mathrm{x}} \pm \mathrm{s}(\%)$ & Range (\%) \\
\hline $5.0-5.9$ & 11 & $62.9 \pm 10.7^{*}$ & $40-78$ \\
$6.0-7.2$ & 11 & $51.2 \pm 15.3$ & $23-76$ \\
\hline
\end{tabular}

* Not significantly different from the group with urine $\mathrm{pH}$ 6.0-7.2.

\section{Preparation of urine samples for isomer analysis}

An improved sample preparation method for the analysis of urinary coproporphyrin isomers I-IV was developed. First, porphyrinogens present in the freshly passed urine specimens were immediately oxidized to the corresponding porphyrins, because the latter are stable to further isomerization. Oxidation was performed with iodine at nearly neutral $\mathrm{pH}$ according to Mauzerall (10) in order to prevent chemical isomerization of porphyrinogens. Strongly acidic conditions for the oxidation step as reported by others $(6,7,11)$ may lead to complete isomerization $(10)$. Porphyrins were then extracted and efficiently purified by use of selective solid-phase sampling techniques with reversed-phase $\mathrm{C}_{18}$ materials and talc as sorbents. Subsequent isocratic ion-pair HPLC analysis produced clean chromatograms, with no detectable contaminants (fig. 1). The results were compar-

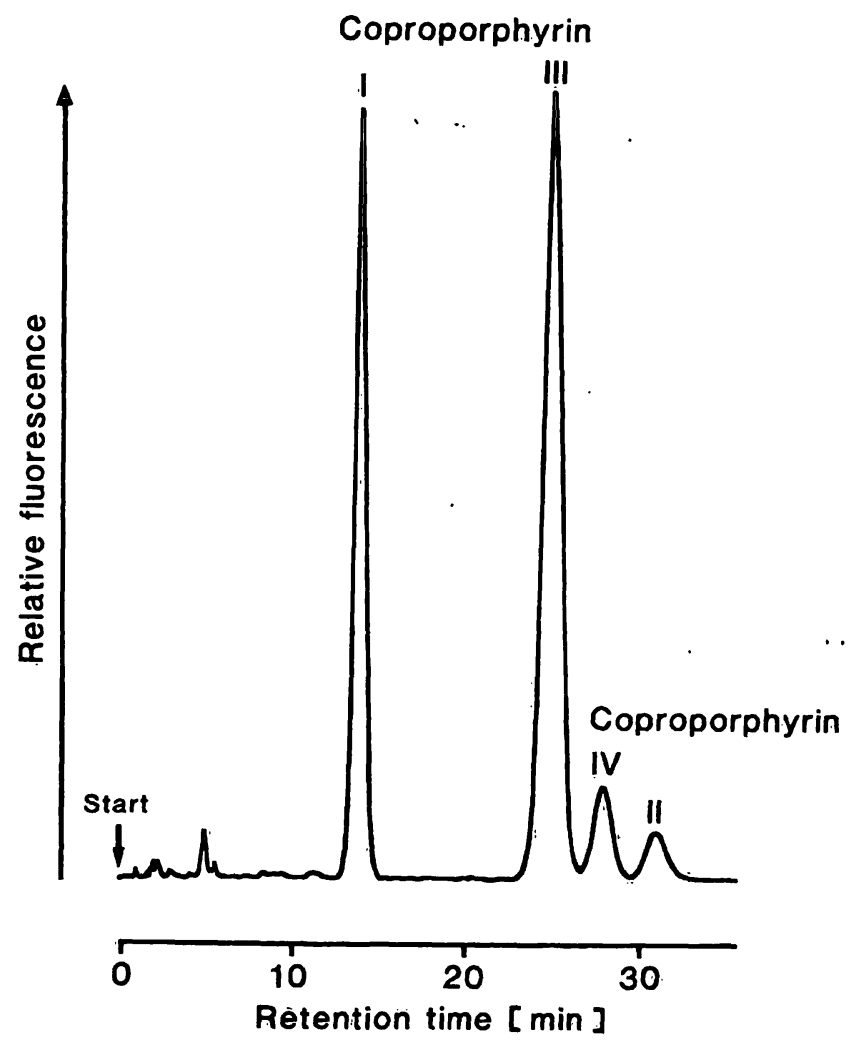

Fig. 1. HPLC separation of coproporphyrin isomers I-IV from an acidic urine (pH 5.3) of a healthy person after combined solid-phase purificätion steps. 
able with those of the thin-layer chromatographic (TLC) purification method used in previous studies $(2,3)$. The advantage of the newly developed technique is a tenfold reduction of sample volume. This is achieved by omitting the TLC purification procedure, which requires additional preparation steps, e.g., extraction, esterification, and saponification of the respective porphyrin methyl esters. Due to the low porphyrin content of non-porphyric urines, sample volumes of $50 \mathrm{ml}$ are necessary to obtain a complete isomer profile.

Relationship between coproporphyrin isomer ratios and urinary $\mathrm{pH}$

The $\mathrm{pH}$-dependence of coproporphyrin isomer ratios was determined in 34 freshly passed urine specimens from healthy subjects. Table 2 displays the results for the individual isomers in acidic urines ( $\mathrm{pH} 5.0$ to 6.0) and in nearly neutral urines ( $\mathrm{pH} 6.1$ to 7.6). The mean content of coproporphyrin III was approximately $10 \%$ lower in acidic urines compared with that in neutral urines $(p<0.001)$. On the other hand, acidic urines contained significantly higher levels of isomers I, II, and IV than neutral urines $(p<0.001)$. These effects were especially evident in the case of the atypical isomers II and IV. Here we found in acidic urines up to $5 \%$ of isomer II and $7 \%$ of isomer IV, whereas neutral urines contained only 0.1 to $0.3 \%$.

To confirm these results, we demonstrated the arbitrary alteration of the respective isomer ratios by enforced shifting of the urinary $\mathrm{pH}$ value in an individual subject. Thus, from one person, we analysed 13 different urine specimens, with $\mathrm{pH}$ values between 5.4 and 7.3 (tab. 3). Under the experimental conditions applied, we observed the same relationship between coproporphyrin isomer ratios and urinary $\mathrm{pH}$ value as established for the whole study group (fig. $2 a-d)$.

The strong influence of urine $\mathrm{pH}$ on the excretion rates of the individual coproporphyrin isomers can be explained by increased isomerization of coproporphyrinogens in vitro under relatively acidic conditions (3). In vivo, the predominantly occurring isomer III is non-enzymatically converted to the isomers $\mathrm{I}, \mathrm{II}$, and IV. This reaction is accelerated by acidic conditions. In neutral urines the isomerization rate is markedly reduced, and consequently higher proportions of isomer III are excreted combined with lower proportions of isomer I and only trace amounts of isomers II and IV. In addition, the isomerization rate is influenced by the retention time and temperature of urine in the human bladder. These factors were not standardized in our study, and therefore relatively wide
Tab. 2. Effect of urinary pH on the isomeric composition of coproporphyrins I-IV in 34 freshly passed urine specimens. Data are expressed as percentage of total urinary coproporphyrins.

\begin{tabular}{lllll}
\hline Coproporphyrins & I & II & III & IV \\
\hline Urine pH 5.0-6.0 & & & & \\
$(\mathrm{N}=18)$ & & & & \\
Mean (\%) & $27.1^{*}$ & $2.7^{*}$ & $65.2^{*}$ & $5.0^{*}$ \\
s (\%) & 6.4 & 1.1 & 7.9 & 1.3 \\
Range (\%) & $18-39$ & $1.1-5.0$ & $51-75$ & $3.0-7.2$ \\
& & & & \\
Urine pH 6.1-7.6 & & & & \\
$(\mathrm{N}=16)$ & & & & \\
Mean (\%) & 22.0 & 0.6 & 75.9 & 1.5 \\
s (\%) & 5.1 & 0.6 & 5.4 & 1.3 \\
Range (\%) & $12-31$ & $0.1-2.5$ & $67-87$ & $0.1-5.2$ \\
\hline
\end{tabular}

* Significantly different $(p<0.001)$ from the group with urine pH 6.1 - 7.6.

Tab. 3. Effect of urinary pH on the isomeric composition of coproporphyrins I-IV in 13 freshly passed urine specimens from an individual healthy subject. Data are expressed as percentage of total urinary coproporphyrins.

\begin{tabular}{lllll}
\hline Coproporphyrins & I & II & III & IV \\
\hline Urine pH 5.4-6.0 & & & & \\
(N=6) & & & & \\
Mean (\%) & 27.6 & 2.1 & 66.1 & 4.2 \\
s (\%) & 2.2 & 0.6 & 3.7 & 1.6 \\
Range (\%) & $24-30$ & $1.6-3.4$ & $60-72$ & $2.7-6.7$ \\
Urine pH 6.1-7.3 & & & & \\
(N=7) & & & & \\
Mean (\%) & 21.1 & 0.8 & 75.9 & 2.2 \\
s (\%) & 3.0 & 0.5 & 2.3 & 1.2 \\
Range (\%) & $17-25$ & $0.2-1.9$ & $73-80$ & $0.3-4.1$ \\
\hline
\end{tabular}

ranges of the respective isomer ratios were found, particularly in the case of isomer $\cdot$ I. In vitro kinetic experiments revealed a clearly time-dependent influence on the isomerization rate of coproporphyrinogen III. Thus, after $18 \mathrm{~h}$ at pH 5.2 and $37^{\circ} \mathrm{C}$, we observed an isomerization rate of $21 \%$ (corresponding to $5.6 \%$ isomer I, $5.2 \%$ isomer II, and $10.2 \%$ isomer IV) (unpublished results). After $24 \mathrm{~h}$, under the same conditions, we found $29.8 \%$ isomerization (corresponding to $7.8 \%$ isomer I, $7.9 \%$ isomer II, and $14.1 \%$ isomer IV) (3).

In healthy subjects, the relative percentages of urinary coproporphyrins I and III are 25 and $75 \%$, respectively (12). It is well known that these isomer ratios are considerably changed either by primary porphyrias, e.g., congenital erythropoietic porphyria, or by secondary coproporphyrinurias, e.g., in patients with certain types of liver diseases, Dubin-Jolnnson syndrome and Rotor's syndrome (12). These deviations 

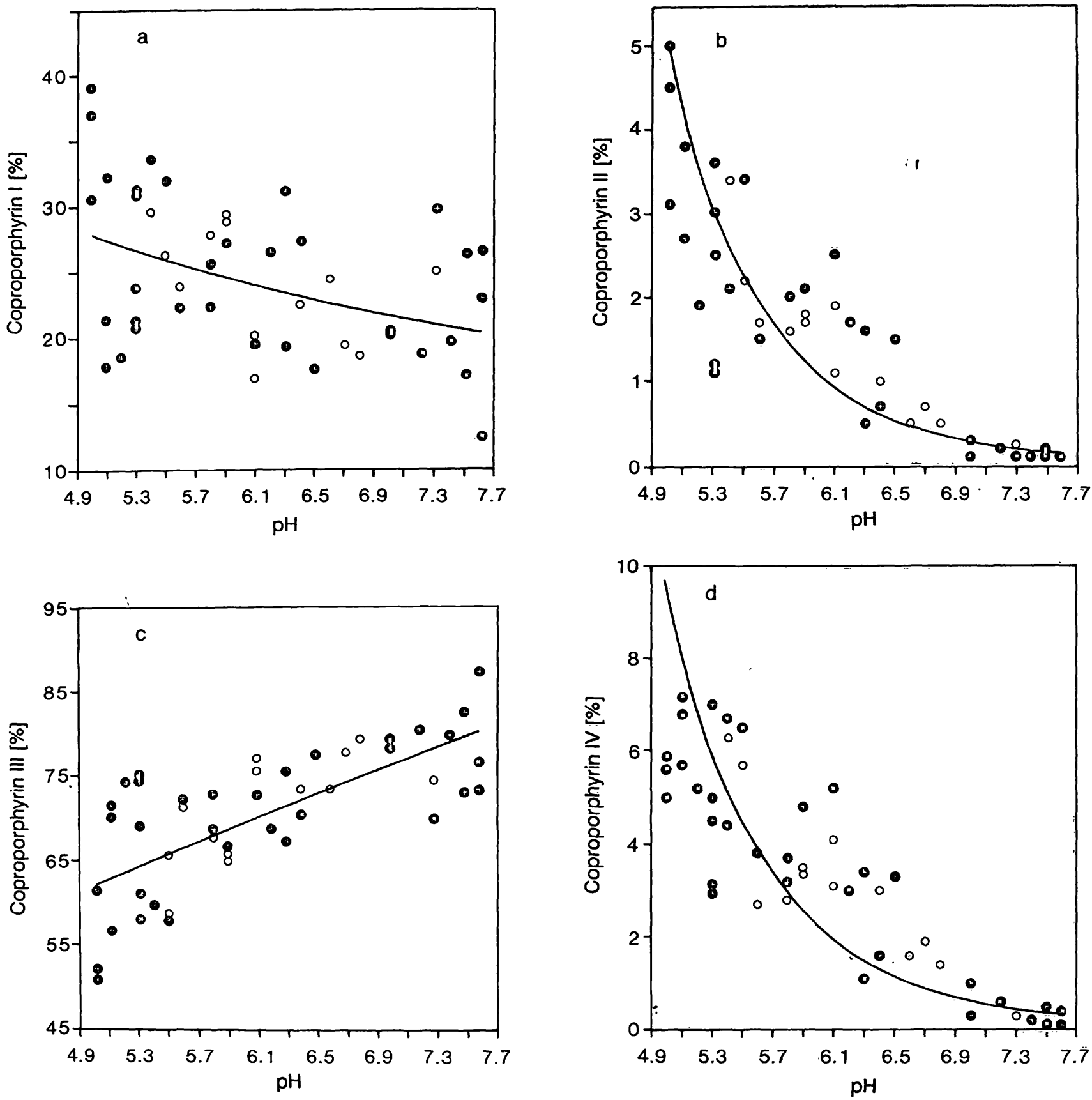

Fig. 2. Effect of urinary $\mathrm{pH}$ on the excretion of coproporphyrins (percentage of total coproporphyrins) in the urine of an individual subject $(0)$ and the whole study group $(0)$. $a=$ coproporphyrin I $b=$ coproporphyrin II $c=$ coprophorphyrin III $\quad d=$ coproporphyrin IV

are due to altered activities of enzymes involved in the biosynthesis of haem or by impaired coproporphyrin transport mechanisms (13). The methodology previously used for the estimation of urinary porphyrin isomer ratios allowed only the determination of isomers I and III. However, two independent HPLC techniques are available for the simultaneous separation of all four coproporphyrin isomers, namely the hydrophobic interaction technique (14) and the ion-pair technique $(2,15)$. Application of these advanced separation methods to the $\mathrm{pH}$-related analysis of urinary coproporphyrins from patients with abnormal isomer distribution might be helpful for fur- ther elucidation of the underlying excretion mechanisms.

In conclusion, measurement of coproporphyrin isomers I-IV in urines of healthy subjects exhibited an unexpected influence of urinary $\mathrm{pH}$ on the excretion rates of the individual isomers. Alteration of the respective isomer ratios can be explained by non-enzymatic, intravesical isomerization of the naturally occurring coproporphyrinogens. It is suggested that the non-enzymatic change of side-chain sequence on the intact porphyrinogen molecule might be initiated by acid-catalysed ring-opening and rearrangement via spiro-cyclic intermediates $(16)$ : : 
Further studies, such as $\mathrm{pH}$-related investigation of coproporphyrin isomer ratios in different clinical materials, will test the usefulness of the technique described here and may contribute to a better understanding of the metabolism of porphyrin isomers.

\section{References}

1. Jacob, K., Egeler, E., Hennel, B. \& Neumeier, D. (1988) Improved separation of porphyrin isomers from human urines by isocratic ion-pair HPLC. Fresenius Z. Anal. Chem. 330, 386-387.

2. Jacob, K., Egeler, E., Neumeier, D. \& Knedel, M. (1989) Isocratic ion-pair high-performance liquid chromatographic methods for the determination of uroporphyrin and coproporphyrin type II and IV isomers in human urine. J. Chromatogr. 468, 329-338.

3. Jacob, K., Egeler, E., Hennel, B. \& Luppa, P. (1989) Coproporphyrin isomers II and IV are normal constituents of human urine. J. Clin. Chem. Clin. Biochem. 27, 659-661.

4. Moore, M. R., McColl, K. E. L., Rimington, C. \& Goldberg, A. (1987) Disorders of porphyrin metabolism, p. 59, Plenum Publishing Corporation, New York, London.

5. Watson, C. J., Pimenta de Mello, R., Schwartz, S., Hawkinson, V. E. \& Bossenmaier, I. (1951) Porphyrin chromogens or precursors in urine, blood, bile, and feces. J. Lab. Clin. Med. 37, $831-842$.

6. Martasek, P., Jirsa, M. \& Kordac, V. (1982) Porphyrinogens in urine in various types of porphyrias. J. Clin. Chem. Clin. Biochem. 20, 113-117.

7. Abe, K. \& Konaka, R. (1989) Quantification of urinary porphyrins by liquid chromatography after oxidation of porphyrinogens. Clin. Chem. 35, 1619-1622.

8. Jacob, K., Egeler, E. \& Luppa, P. (1990) High-performance liquid chromatographic investigations on the formation of coproporphyrin isomers II and IV in human urine. Fresenius J. Anal. Chem. 337, 61-62.

\section{Acknowledgement}

The financial support of this work by the Hans-Fischer-Gesellschaft (Munich) is gratefully acknowledged.

9. Schmitt, A. (1977) Bestimmung der Gesamtporphyrine in Urin durch Derivativ-Spektroskopie. J. Clin. Chem. Clin. Biochem. 15, 303-306.

10. Mauzerall, D. (1960) The thermodynamic stability of porphyrinogens. J. Amer. Chem. Soc. 82, 2601-2605.

11. Westerlund, J., Pudek, M. \& Schreiber, W. E. (1988) A rapid and accurate spectrofluorometric method for quantification and screening of urinary porphyrins. Clin. Chem. $34,345-351$.

12. Doss, M. (1989) Porphyrinstoffwechsel, In: Lehrbuch der Klinischen Chemie und Pathobiochemic, 2nd edn. (Greiling, H. \& Gressner, A. M., eds.) pp. 311-339, Schattauer Verlagsgesellschaft, Stuttgart, New York.

13. Frank, M. \& Doss, M. O. (1989) Relevance of urinary coproporphyrin isomers in hereditary hyperbilirubinemias. Clin. Biochem. 22, 221-222.

14. Wright, D. J., Rideout, J. M. \& Lim, C. K. (1983) Highperformance liquid chromatography of coproporphyrin isomers. Biochem. J. 209, 553-555.

15. Jacob, K., Sommer, W., Meyer, H. D. \& Vogt, W. (1985) Ion-pair high-performance liquid chromatographic separation of porphyrin isomers. J. Chromatogr. 349, 283293.

16. Mathewson, J. H. \& Corwin, A. H. (1961) Biosynthesis of pyrrole pigments: a mechanism for porphobilinogen polymerization. J. Amer. Chem. Soc. 83, 135-137.

Prof. Dr. K. Jacob

Institut für Klinische Chemie

am Klinikum Großhadern

der Universität München

Marchioninistr. 15

W-8000 München 70

Bundesrepublik Deutschland 
L 


\section{Peptides 1988}

\section{Proceedings of the 20th European Peptide Symposium}

September 4-9, 1988 . University of Tibingen

Tiubingen, Federal Republic of Germany

1989. $17 \times 24 \mathrm{~cm} . \mathrm{LX}, 795$ pages. With numerous illustrations.

Hardcover. DM 386,-; approx. US \$ 193.00 ISBN 3110109492

The development of peptide chemistry and its increased importance in various fields of biochemistry, biology and medicine has been well documented in the Proceedings of the European Peptide Symposia.

Peptides 1988 presents contributions from scientists all over the world to the 20th Peptide Symposium.

\section{From the Contents}

Methodology of Synthesis - Peptides with Unusual and Modified Residues · Physical Studies on Peptides - Hormones, Receptors and Structure-Activity Relationships Immunochemistry $\cdot$ Author Index $\cdot$ Subject Index

Also available:

\section{Peptides 1982}

\section{Editors Blàha, Malŏn}

1983. $17 \mathrm{~cm} \times 24 \mathrm{~cm}$. LVI, 846 pages. DM 280,- ISBN 3110095742

\section{Peptides 1986}

Editor Theodoropoulos

1987. $17 \mathrm{~cm} \times 24 \mathrm{~cm}$. XIX, 684 pages. DM 320,- ISBN 3110106876 


\section{Biochemistry of Peptide Antibiotics}

\section{Recent Advances in the Biotechnology of $\beta$-Lactams and Microbial Bioactive Peptides}

\section{Editors: Horst Kleinkauf, Hans von Döhren}

1990. $17 \mathrm{~cm}$ x $24 \mathrm{~cm}$. XIV, 522 pages. With numerous illustrations. Hardcover. DM 310,-; approx. US \$ 182.00 ISBN 3110119285

Peptide Antibiotics, $\beta$-Lactams and bioactive Peptides have maintained a significant position in research and applications. Classical Cyclopeptides like Gramicidin S, Cyclosporin, Bleomycins, the various Proteinase Inhibitors, Siderophores, new $\beta$-Lactams and Vancomycin type Glycopeptides are presented from their representative leads in basic research in biosynthesis, genetics, chemistry, pharmacology, and biotechnology. The main developments of the last years have been reviewed, and structural information on naturally occurring Peptides has been compilẹ.

This monograph will serve researchers in the Peptide field as source and reference book.

\section{From the Contents}

Bioactive Peptides - Recent Advances and Trends - Gramicidin S Synthetase - Formation on $N$ methylated Peptide Bonds in Peptides and Peptidols - Peptide Bond Synthesis by Enzyme-Catalyzed Acyl-Transfer - Genetics of Siderophore Biosynthesis and Transport - Discovery of new $\beta$-Lactam and $\beta$-Lactam like Antibiotics from Bacteria - Glycopeptide Antibiotics of the Vancomycin Group - Peptide Phytotoxins from Plant Pathogenic Fungi - Chemical Synthesis and Bioactivity of Gramicidin S and Related Peptides - Cyclosporine: Synthetic Studies, StructureActivity Relationships, Biosynthesis and Mode of Action - Biosynthesis and Chemical Synthesis of Bleomycin - Small Molecular Protease Inhibitors and Their Biological Effects - Directed Biosynthesis of Neoviridogriseins - Biochemical Genetical and Biotechnical Aspects of Antibiotic Production via Immobilised Biocatalysis - Compilation of Peptide Structures - A Biogenetic Approach $\cdot$ Contributors $\cdot$ Index 